Agro-Science Journal of Tropical Agriculture, Food, Environment and Extension Volume 19 Number 1 (January 2020) pp. $49-53$

ISSN 1119-7455

\title{
ON-FARM EVALUATION OF THREE STRAINS OF Lactobacillus sp. BASED PROBIOTICS ON THE HEMATOLOGY AND SERUM LIPID PROFILE OF LOCAL TOMS
}

\author{
"Dim C.E., Ogwuegbu M.C. and Onyimonyi A.E. \\ Department of Animal Science, University of Nigeria, Nsukka, Nigeria \\ *Corresponding author's email: chinonso.dim@unn.edu.ng
}

\begin{abstract}
A 16-week study was conducted to determine the effect of three strains of Lactobacillus sp based probiotics on hematological indices and serum lipid profile of local toms. A total of 80-day-old local male poults were randomly assigned to four treatments (T1, T2, T3 and T4) in a completely randomized design with 20 birds per treatment. Three strains of Lactobacillus namely L. delbrueckii sub sp. bulgaricus, L. acidophilus and L. sporogens were incorporated in the drinking water of T2, T3, and T4 respectively at $0.5 \mathrm{ml} / \mathrm{L}$. T1 served as control. Each treatment was replicated twice with 10 birds per replicate. Feed and water were provided ad libitum. Results showed that the effect of the different strains of Lactobacillus sp. on hemoglobin, red blood cell count, white blood cell count, serum triglycerides, cholesterol, high-density lipoproteins and low-density lipoproteins were significant $(p<0.05)$. Birds on probiotics inclusion had least values for white blood cell counts, low-density lipoproteins, cholesterol and serum triglycerides with $\mathbf{T 4}$ recording the most superior values. It was thus concluded that of the three strains of Lactobacillus sp based probiotics used in the study, Lactobacillus sporogens was observed to support superior hematological values with reduced lipid profiles.
\end{abstract}

Key words: direct-fed microbials, fat accretion, health status, Lactobacillus sp., turkey production

\section{INTRODUCTION}

Despite its greater potential than the chicken, turkey production has not been fully exploited in the developing countries (Perez-Lara et al., 2013). Most research works on poultry are focused on the chicken with paucity of attention on turkeys (Speller, 2009). In the tropics, turkey thrives better than the domestic chicken. It manages heat stress better and has superior meat quality than the average chicken (Prabakaran, 2003; Yakubu et al., 2013).

Fat accretion in poultry cut parts and visceral organs is an indication of waste to poultry product consumers. These consumers are ever more concerned about the nutritional and health benefit of their foods (Oso et al., 2011). Fat reduction and improvement of hematological parameters in poultry birds have thus become a focal point for nutritional research as they serve as credible tools in disease diagnosis and assessment of health status in animals (Theml et al., 2004). Several dietary manipulations have been used over the decades for diminution of fats in the blood and serum of poultry, including the use of probiotics (Cetin et al., 2005; Ahmad, 2006; Ashayerizadeh et al., 2009).
Probiotics are mono- or mixed cultures of 'live' microorganisms (Osita et al., 2019). They are mainly Lactobacillus sp. and when well administered confer health benefits on the host (FAO/WHO, 2002). The ban on the use of antibiotics in poultry production necessitated the advent and use of probiotics in poultry production as alternatives (Edens, 2003). Currently, the best studied probiotics are the lactic acid bacteria, particularly Lactobacillus sp. and Bifidobacterium sp. (Vahjen et al., 2002; Bielke et al., 2003; Priyankarage et al., 2004; Berrin, 2011).

Effects of Lactobacillus sp. on production and their mode of action in monogastric animals have been reported in poultry (Panda et al., 2007; Apata, 2008; Willis and Reid, 2008; Ashayerizadeh et al., 2009; Awad et al., 2009). The species currently used in probiotic preparations are varied and many. These are mostly Lactobacillus bulgaricus, L. acidophilus, L. casei, L. helveticus, L. lactis, L. salivarius, $L$. plantarum (Jin et al., 2000; Christensen et al., 2002; Lammers et al., 2003; Rakoff-Nahoum et al., 2004). The current study therefore seeks to determine the effect of three Lactobacillus strains on hematological indices and serum lipid profile of local toms. 
Table 1: Percentage composition of experimental diets

\begin{tabular}{llll}
\hline Ingredients & Starter $(\%)$ & Grower (\%) & Finisher (\%) \\
\hline Maize & 45.00 & 48.00 & 50.00 \\
Soybean meal & 40.00 & 37.00 & 24.10 \\
Fishmeal & 7.30 & 4.50 & 1.50 \\
Wheat offal & 0.00 & 4.00 & 17.55 \\
Bone meal & 4.30 & 3.20 & 3.65 \\
Oyster shell & 2.50 & 2.50 & 2.50 \\
Vitamin Premix* & 0.25 & 0.25 & 0.25 \\
Salt & 0.25 & 0.25 & 0.25 \\
DL-methionine & 0.30 & 0.20 & 0.10 \\
Lysine & 0.10 & 0.10 & 0.10 \\
Total & 100 & 100 & 100 \\
Calculated composition & & \\
Crude protein (\%) & 26.00 & 22.40 & 19.50 \\
Crude fibre (\%) & 3.90 & 4.26 & 4.65 \\
Ether extract (\%) & 5.00 & 4.52 & 4.31 \\
ME (K cal/Kg) & 2845.00 & 3100.00 & 3150.00 \\
\hline *Each 2.25 kg of vitamin premix contains 10,000,000 I.U. Vit. A, \\
2,200,000 I.U Vit. D3, 10,000 mg Vit. E, 2000 mg Vit. K3, 1500 mg Vit. \\
B1, 5000 mg Vit. B2, 1500 mg, Vit. B6, 10 mg Vit. B12, 15,000 mg Niacin, \\
20 mg biotin, 125,000 mg anti-oxidant, 500 mg, Folic acid, 5000 mg Calpan
\end{tabular}

\section{MATERIALS AND METHODS}

\section{Location and Duration of Study}

The study was conducted at the Turkey Unit of Sabugo Farms Limited, Umuakashi Industrial Layout, Nsukka. Nsukka lies within longitude $6^{\circ}$ $45^{\prime} \mathrm{E}$ and $7^{\circ} \mathrm{E}$ and latitude $7^{\circ} 12.5^{\prime} \mathrm{N}$ and on the altitude $447 \mathrm{~m}$ above sea level. The climate of the study area is typically tropical, with relative humidity ranging from 65 to $80 \%$ and mean daily temperature of $26.8^{\circ} \mathrm{C}$ (Agbagha et al., 2000). The study lasted for 16 weeks.

\section{Test Strains}

The three strains of Lactobacillus-based probiotics used in the study were Lactobacillus sporogenes NRRL-4496 $\left(1 \times 10^{8} \mathrm{CFU} / \mathrm{mL}\right)$, L. delbrueckii subspecies bulgaricus NRRL B-4527 $\left(1 \times 10^{8}\right.$ CFU/mL $)$ and L. acidophilus NRRL-4495 $\left(1 \times 10^{8}\right.$ $\mathrm{CFU} / \mathrm{mL}$ ). They were obtained and constituted in a broth, from the Microbial Genomics and Bioprocessing Research Unit, National Centre for Agricultural Utilization Research, Agricultural Research Service, United States Department of Agriculture, University Street, Peoria, Illinois.

\section{Experimental Diets}

Three experimental diets were formulated for the starter (0-8 weeks), grower (9-12 weeks) and finisher (13-16 weeks) phases of the experiment. The percentage compositions of the experimental diets are presented in Table 1.

\section{Management of Experimental Birds}

The experiment was carried out in accordance with the provisions of the Ethical Committee on the use of animals and humans for biomedical research of the University of Nigeria, Nsukka. A total of 80 day old male poults were randomly divided into 4 groups of 20 birds each. Each group was randomly assigned to four treatments T1, T2, T3, and T4, using a completely randomized design (CRD). Each treatment was replicated twice with 10 birds per replicate placed in deep litter system.
Birds on T2, T3 and T4 received probiotics of $L$. delbrueckii subspecies bulgaricus, L. acidophilus and $L$. sporogenes respectively at inclusion levels of $0.5 \mathrm{ml} / \mathrm{L}\left(10^{6} \mathrm{CFU} / \mathrm{mL}\right)$ in their drinking water for 3 consecutive days from 1-3, 10-12 and 21-23 days of age to achieve the recommended microbial concentration as stipulated by the supplier. In order to protect the probiotic organisms, $0.5 \mathrm{~kg}$ of powder milk/1000L was added to their drinking water. T1 served as control with no strain of Lactobacillus inclusion. Feed and water were supplied ad libitum to the birds.

\section{Collection of Blood Samples}

Blood samples (about $2.5 \mathrm{ml}$ each) were collected from the wing vein of five toms per replicate at the end of 8th, 12th and 16th weeks of study. A set was collected in EDTA bottles for the determination of hematological indices while another set was collected in plain tubes without EDTA. Plasma was collected subsequently by centrifuging at $3000 \mathrm{rpm}$ for $15 \mathrm{~min}$. as described by Hayat et al. (1993).

\section{Statistical Analyses}

Data collected were subjected to One way analysis of variance (ANOVA) using a statistical package (SAS, 2006) windows version 8.0 and mean differences were separated using Duncan's New Multiple Range Test as outlined by Obi (2002).

\section{RESULTS AND DISCUSSION}

Effect of Three Strains of Lactobacillus sp. Based Probiotics on Hematological Indices of Local Toms Effect of three strains of Lactobacillus sp. on haematological indices of local toms was shown in Table 2. There were significant $(p<0.05)$ differences among treatment means on hemoglobin, red blood cell counts and white blood cell counts. The packed cell volume of the birds was however found to be non-significant $(p>0.05)$ all through the birds' growing phases: starter ( 8 weeks of age), grower (12 weeks of age) and finisher (16 weeks of age). The birds on the Lactobacillus sp. based probiotics inclusion (T2, $\mathrm{T} 3$ and T4) recorded lower values for the white blood cell count than the birds on the control group with T4 (L. sporogens) having the least $(p<0.05)$ values $\left(19860.00 \mathrm{cumm}^{3}, 19853.80 \mathrm{cumm}^{3}\right.$ and 22650.00 cumm $^{3}$ for the birds' starter, grower and finisher phases, respectively).

These values decreased progressively with age. This is an indication that birds on probiotics treatment were not under any disease threat, as the normal range of values spans between 19400 and 24000 cumm $^{3}$ (Alberts, 2005). Birds on T2, T3 and T4 also recorded high values for hemoglobin and red blood cell counts with T3 (L. acidophilus) having the highest values at the starter phase. However, birds on T4 recorded highest values during the finisher phase. These high values can also 
Table 2: Effect of three strains of Lactobacillus sp based probiotics on hematological indices of local toms

\begin{tabular}{|c|c|c|c|c|c|c|}
\hline & Parameters & & & eatments & & \\
\hline & & $\mathrm{T} 1$ & $\mathrm{~T} 2$ & $\mathrm{~T} 3$ & $\mathrm{~T} 4$ & SEM \\
\hline & Packed cell volume (\%) & 38.98 & 38.94 & 39.00 & 38.80 & 0.54 \\
\hline$\tilde{y}$ & Hemoglobin $(\mathrm{g} / \mathrm{dl})$ & $10.71^{\mathrm{c}}$ & $11.70^{\mathrm{b}}$ & $13.20^{\mathrm{a}}$ & $11.59^{\mathrm{b}}$ & 0.22 \\
\hline 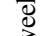 & Red blood cell $\left(\times 10^{12} / 1\right)$ & $2.40^{\mathrm{c}}$ & $3.13^{\mathrm{b}}$ & $3.81^{\mathrm{a}}$ & $2.94^{\mathrm{b}}$ & 0.03 \\
\hline $\begin{array}{l}3 \\
\infty\end{array}$ & White blood cell (cumm $\left.{ }^{3}\right)$ & $31140.00^{\mathrm{a}}$ & $28225.00^{\mathrm{b}}$ & $27480.00^{\mathrm{c}}$ & $19860.00^{\mathrm{d}}$ & 1529.45 \\
\hline & Packed cell volume $(\%)$ & 32.10 & 33.40 & 32.40 & 31.01 & 1.66 \\
\hline$\frac{y}{2}$ & Hemoglobin $(\mathrm{g} / \mathrm{dl})$ & $9.18^{\mathrm{c}}$ & $10.19^{\mathrm{b}}$ & $10.90^{\mathrm{a}}$ & $10.10^{\mathrm{b}}$ & 0.40 \\
\hline$\frac{0}{3}$ & Red blood cell (x10¹/1) & $2.48^{\mathrm{c}}$ & $2.59^{\mathrm{b}}$ & $3.28^{\mathrm{a}}$ & $2.60^{\mathrm{b}}$ & 0.10 \\
\hline ב & White blood cell $\left(\mathrm{cumm}^{3}\right)$ & $26337.10^{\mathrm{a}}$ & $24250.00^{\mathrm{b}}$ & $20094.10^{c}$ & $19953.80^{\mathrm{c}}$ & 709.10 \\
\hline & Packed cell volume $(\%)$ & 29.00 & 31.00 & 30.00 & 30.60 & 1.40 \\
\hline$\frac{n}{2}$ & Hemoglobin $(\mathrm{g} / \mathrm{dl})$ & $9.19^{\mathrm{c}}$ & $9.92^{\mathrm{b}}$ & $10.01^{\mathrm{b}}$ & $14.00^{\mathrm{a}}$ & 0.33 \\
\hline$\sum_{\infty}^{\infty}$ & Red blood cell $\left(\times 10^{12} / 1\right)$ & $2.46^{\mathrm{b}}$ & $2.50^{\mathrm{b}}$ & $2.47^{\mathrm{b}}$ & $3.39^{\mathrm{a}}$ & 0.10 \\
\hline & White blood cell $\left(\mathrm{cumm}^{3}\right)$ & $26110.00^{\mathrm{a}}$ & $23400.00^{\mathrm{b}}$ & $22900.00^{\mathrm{b}}$ & $22650.00^{\mathrm{b}}$ & 701.68 \\
\hline
\end{tabular}

be attributed to the role of these strains of Lactobacillus sp. in the synthesis of vitamin $\mathrm{B}_{12}$ which is implicated in the production of erythrocytes in the bone marrows, and also vitamin E which acts as an antioxidant to prevent erythrocyte destruction and promote hemoglobin concentration. It has been reported that probiotic bacteria produce $\mathrm{B}$ vitamins, such as folic acid, niacin, riboflavin, $\mathrm{B}_{12}, \mathrm{~B}_{6}$ and pantothenic acid (Leblanc et al., 2011), which are biocatalysts in food metabolism and help to fight stress. These results agree with the work of Cetin et al. (2005) who reported significant increase in the erythrocyte count, hemoglobin concentration and hematocrit values of turkeys fed probiotics.

\section{Effect of Three Strains of Lactobacillus sp Based} Probiotics on Serum Lipid Profile of Local Toms Table 3 shows the effect of three strains of Lactobacillus sp. on serum lipid profile of local toms. There were significant $(p<0.05)$ differences among treatments on cholesterol, triglycerides, high-density lipoprotein and low-density lipoproteins. However, a non-significant difference $(p>0.05)$ was observed among the treatments in the birds' values for high-density lipoproteins during the starter phase ( 8 weeks of age). The birds on Lactobacillus sp. based probiotics inclusion (T2, T3, and T4) recorded lower values of cholesterol and low-density lipoproteins than those in the control group as the birds mature, with $\mathrm{T} 4$ (L. sporogens) having the least values for starter, grower and finisher phases. The birds' cholesterol levels during the 8 and 12 weeks of age were statistically similar $(p<0.05)$ for birds on probiotics inclusion despite the difference in their numerical values. But as they aged, their cholesterol values differed significantly $(p<0.05)$ among the treatments. The birds' low-density lipoproteins values also differed $(p<0.05)$ among the treatments during the finisher phase, with T4 having the least $(p<0.05)$ value among the treatment groups. The birds on probiotic inclusions also recorded higher $(p<0.05)$ values of high-density lipoproteins than the control group with $\mathrm{T} 4$ recording the highest $(p<0.05)$ values during the $12^{\text {th }}$ and $16^{\text {th }}$ weeks of age (45.25 and $41.30 \mathrm{mg} / \mathrm{dl}$, respectively). Birds on T4 recorded least $(p<0.05)$ values for serum triglycerides for starter, grower and finisher phases. This reduction in the level of cholesterol, lowdensity lipoproteins and triglycerides observed in the birds on Lactobacillus sp. based probiotics can be attributed to anticholesterolemic effect of these bacteria. Chen et al. (2016) and Jeun et al. (2010) reported that lactic acid bacteria possess anticholesterolemic and antilipidemic factors which aided in cholesterol reduction. This is in tandem with the reports of Xie et al. (2011) and Panda et al. (2007) who observed anticholesterolemic effects of Lactobacillus sp. when fed to food animals.

Table 3: Effect of three strains of Lactobacillus sp. based probiotics on serum lipid profile of local toms

\begin{tabular}{|c|c|c|c|c|c|c|}
\hline \multirow{2}{*}{\multicolumn{2}{|c|}{ Parameters }} & \multicolumn{5}{|c|}{ Treatments } \\
\hline & & $\mathrm{T} 1$ & $\mathrm{~T} 2$ & T3 & $\mathrm{T} 4$ & SEM \\
\hline \multirow{4}{*}{$\frac{\pi}{d}$} & Cholesterol (mg/dl) & $141.50^{\mathrm{a}}$ & $131.20^{\mathrm{b}}$ & $131.03^{b}$ & $130.90^{\mathrm{b}}$ & 0.10 \\
\hline & Triglycerides (mg/dl) & $100.50^{\mathrm{c}}$ & $120.00^{\mathrm{a}}$ & $103.74^{\mathrm{b}}$ & $93.30^{\mathrm{d}}$ & 2.36 \\
\hline & $\mathrm{HDL}(\mathrm{mg} / \mathrm{dl})$ & 39.33 & 39.42 & 40.62 & 39.72 & 0.18 \\
\hline & $\mathrm{LDL}(\mathrm{mg} / \mathrm{dl})$ & $82.80^{\mathrm{a}}$ & $78.05^{\mathrm{b}}$ & $77.96^{\mathrm{b}}$ & $77.70^{\mathrm{b}}$ & 0.11 \\
\hline \multirow{4}{*}{$\begin{array}{l}\frac{\pi}{d} \\
\frac{0}{2} \\
\mathcal{Z}\end{array}$} & Cholesterol (mg/dl) & $194.50^{\mathrm{a}}$ & $158.25^{\mathrm{b}}$ & $146.81^{\mathrm{c}}$ & $124.40^{\mathrm{d}}$ & 6.70 \\
\hline & Triglycerides (mg/dl) & $120.20^{\mathrm{a}}$ & $114.10^{\mathrm{b}}$ & $111.01^{\mathrm{b}}$ & $106.25^{\mathrm{c}}$ & 2.47 \\
\hline & $\mathrm{HDL}(\mathrm{mg} / \mathrm{dl})$ & $40.69^{c}$ & $41.57^{\mathrm{b}}$ & $41.44^{\mathrm{b}}$ & $45.25^{\mathrm{a}}$ & 1.36 \\
\hline & $\mathrm{LDL}(\mathrm{mg} / \mathrm{dl})$ & $122.01^{\mathrm{a}}$ & $68.51^{\mathrm{b}}$ & $67.50^{\mathrm{b}}$ & $67.47^{\mathrm{b}}$ & 0.12 \\
\hline \multirow{4}{*}{$\begin{array}{l}0 \\
0 \\
0\end{array}$} & Cholesterol (mg/dl) & $192.64^{\mathrm{a}}$ & $156.48^{\mathrm{b}}$ & $141.45^{\mathrm{c}}$ & $114.34^{\mathrm{d}}$ & 7.20 \\
\hline & Triglycerides (mg/dl) & $128.21^{\mathrm{a}}$ & $110.19^{b}$ & $109.13^{\mathrm{b}}$ & $100.41^{\mathrm{c}}$ & 2.74 \\
\hline & $\mathrm{HDL}(\mathrm{mg} / \mathrm{dl})$ & $30.57^{\mathrm{d}}$ & $33.90^{\mathrm{c}}$ & $37.00^{\mathrm{b}}$ & $41.30^{\mathrm{a}}$ & 1.10 \\
\hline & $\mathrm{LDL}(\mathrm{mg} / \mathrm{dl})$ & $125.20^{\mathrm{a}}$ & $95.45^{\mathrm{b}}$ & $87.54^{\mathrm{c}}$ & $58.62^{\mathrm{d}}$ & 3.43 \\
\hline
\end{tabular}

${ }^{a b c}$ Means on the same row having different superscripts are significantly different $(p<0.05)$, SEM - standard error of mean,

T1 - no probiotics inclusion (control), T2 - L. delbrueckii subsp bulgaricus, T3 - L.acidophilus, T4 - L. sporogens 


\section{CONCLUSION AND RECOMMENDATION}

The results obtained in this study have shown that birds on probiotic inclusions especially those on $\mathrm{T} 4$ (L. sporogens) recorded reduced values of serum triglycerides, low-density lipoproteins and cholesterol than other treatment groups. Lactobacillus sporogens was implicated in the high values of the red blood cell count and hemoglobin concentration of the toms at the later stage of growth. White blood cells count of birds that received $L$. sporogens was least among the treatment groups throughout the growth phases, an indication of the role of L. sporogens in modulating immunity of the birds. Lactobacillus sporogens based probiotic should therefore be used in local toms' nutrition. Nevertheless, mixed cultures of these strains alongside other strains of Lactobacillus or other bacteria based probiotics should be explored by other researchers.

\section{REFERENCES}

Agbagha F.M., Ezema F.U. and Omeke B.C.O. (2000). Studies of management effects on fertility purebred and crossbred exotic gilts in two breeding farms at Nsukka. Nig. J. Anim. Prod., 28 (l), 20

Ahmad I. (2006). Effect of Probiotics on Broilers Performance. Int. J. Poultry Sci., 5 (6), 593-597

Alberts B. (2005). Leukocyte functions and percentage breakdown. Molecular Biology of the Cell. NCBI Bookshelf. Retrieved 15-08-2015

Apata D.F. (2008). Growth performance, nutrient digestibility and immune response of broiler chicks fed diets supplemented with a culture of Lactobacillus bulgaricus. J. Sci. Food Agric., 88, 1253-1258

Ashayerizadeh A., Dabiri N., Ashayerizadeh O., Mirzadeh K.H., Roshanfekr H. and Mamooee M. (2009). Effect of dietary antibiotic, probiotic and prebiotic as growth promoters, on growth performance, carcass characteristics and hematological indices of broiler chickens. Pakis. J. Biol. Sci., 12, 52-57

Awad W.A., Ghareeb K., Abdel-Raheem S. and Böhm J. (2009). Effects of dietary inclusion of probiotic and synbiotic on growth performance, organ weights, and intestinal histomorphology of broiler chickens. Poult. Sci., 88, 49-56

Berrin K.G. (2011). Effects of probiotic and prebiotic (mannanoligosaccharide) supplementation on performance, egg quality and hatchability in quail breeders. Ankara Üniv. Vet. Fak Derg., 58, 27-32

Bielke L.R., Elwood A., Donoghue D., Donoghue A., Newberry L., Neighbor N. and Hargis B. (2003). Approach for selection of individual enteric bacteria for competitive exclusion in turkey poults. Poult. Sci., 82, 1378-1382

Cetin N., Guclu B.K. and Cetin E. (2005). The ettects of probiotics and mannooligosaccharides on some haematological parameters in turkeys. J. Vet. Med. Physio. Pathol. Clin. Med., 52 (6), 263-7
Chen K., Li S., Chen F., Li J. and Luo X. (2016). Regulation of the lactobacillus strains on HMGCoA reductase gene transcription in human hepG2 cells via nuclear factor-kB. J. Microbiol. Biotechnol., 26 (2), 402-7. DOI:10.4014/jmb.1507.07086

Christensen H.R., Frokiaer H. and Pestka J.J. (2002). Lactobacilli differentially modulate expression of cytokines and maturation surface markers in murine dendritic cells. J. Immunol., 168, 171-178

Edens F.W. (2003). An alternative for antibiotic se in poultry. Brazilian J. Poultry Sci., 5 (2), 75-97

FAO/WHO. (2002). Evaluation of health and nutritional properties of probiotics in food including powder milk with live lactic acid bacteria. Report of a Joint FAO/WHO Expert Consultation. Available from: http:www.fao.org /es/ ESN/food/ foodandfoo_probio_en.stm

Hayat, J., Savage T.F. and Mirosh L.W. (1993). The reproductive performance of two genetically distinct lines of medium white turkey hens when fed breeder diets with or without a yeast culture containing Saccharomyces cerevisiae. Animal Feed Science Technology, 43, 291-301

Jeun J., Kim S., Cho S.Y., Jun H.J., Park H.J., Seo J.G., Chung M.J. and Lee S.J. (2010). Hypocholesterolemic effects of Lactobacillus plantarum KCTC3928 by increased bile acid excretion in C57BL/6 mice. Nutrition, 26 (3), 321-30

Jin L.Z., Ho Y.W., Abdullah N. and Jalaludin S. (2000). Digestive and bacterial enzyme activities in broilers fed diets supplemented with Lactobacillus Cultures. Poult. Sci. 79, 886-891

Lammers K.M., Brigidi P., Vitali B., Gionchetti P., Rizzello F., Caramelli E., Matteuzzi D. and Campieri M. (2003). Immunomodulatory effects of probiotic bacteria DNA: IL-1 and IL-10 response in human peripheral blood mononuclear cells. FEMS Immunol. Med. Microbiol., 38, 165-172

LeBlanc J.G., Laino J.E., Juarez del Valle M., Vannini V., Van Sinderen D., Taranto M.P., Font de Valdez G., Savoy de Giori G. and Sesma F. (2011). B-Group vitamin production by lactic acid bacteria-current knowledge and potential applications. J. Applied Microbiol., 111 (6), https://doi.org/10.1111/j.13652672.2011.05157.x

Obi I.U. (2002). Statistical Methods of Detecting Differences between Treatment Means and Research Methodology Issues in Laboratory and Field Experiments. $2^{\text {nd }}$ ed. Express Publ. Ltd. Enugu, Nigeria, pp.13-21

Osita C.O., Ani A.O., Ikeh N.E., Oyeagu C.E., Akuru E.A., Ezemagu I.E. and Udeh V.C. (2019). Growth performance and nutrient digestibility of West African dwarf sheep fed high roughage diet containing Saccharomyces cerevisiae. Agro-Science, 18 (3), 2528. DOI: https://dx.doi.org/10.4314/as.v18i3.5

Oso O.A., Sobayo R., Jegede V., Fafiolu A., Iyasere O.S., Dele P., Bamgbose A. and Cecilia A. (2011). Effect of dietary inclusion of sorghum milling waste on growth response, nutrient utilization, gut characteristics and cecal microflora of weaner rabbits. Animal Sci. J., 82 (3), 468-474 
Panda A.K., Ramarao S.S., Raju M.V. and Sharma S.S. (2007). Effect of probiotic (Lactobacillus sporogenes) feeding on egg production and quality, yolk cholesterol and humoral immune response of whiteleghorn layer breeders. J Sci. Food Agric., 88, 43-47

Perez-Lara E., Camacho- Escobar M.A., Avila-Serrano N.Y., Arroyo-Ledezma, J. Sanchez- Bernal E.I., Torre M.R. and Reyes-Borques V. (2013). Productive evaluation of slow growing Mexican turkeys with different diets in confinement. Open J. Animal Sci., 3 (1), 46-53

Prabakaran, R. (2003). Good practices in planning and management of integrated commercial poultry production in South Asia. FAO Anim. Prod. Health, 159, 71-86

Priyankarage N., Silva S.S.P., Gunawardana G.A., Palliyaguru M.W.C.D., Weerasinghe W.M.P.B., Fernando G.K.C.N. and Chandima R. (2004). Effect of different probiotics against a lethal dose of Salmonella challenge in broiler chickens. British Poult. Sci., 45 (1), 43-45

Rakoff-Nahoum S., Paglino J., Eslami-Varzanenh F., Edberg S. and Medzhitov R. (2004). Recognition of commensal microflora by toll-like receptors is required for intestinal homeostasis. Cell, 118, 229-241

SAS (2006). Statistical analysis system. Biometrics, 10, $1-40$
Speller C. (2009). Investigating Turkey (Meleagris gallapavo) Domestication in the Southwest United States through Ancient Data Analysis. Dissertation Submitted to the Department of Archeology, Simon Fraser University

Theml H., Diem H. and Haferlach T. (2004). Color Atlas of Hematology: Practical Microscopic and Clinical Diagnosis. $2^{\text {nd }}$ Ed., Thieme, New York, pp. 2-7

Vahjen W., Jadamus A. and Simon O. (2002). Influence of a probiotic Enterococcus faecium strain on selected bacterial groups in the small intestine of growing turkey poults. Arch. Anim. Nutr., 56, 419-429

Willis W.L. and Reid L. (2008). Investigating the effects of dietary probiotic feeding regimens on broiler chicken production and Campylobacter jejuni presence. Poult. Sci., 87, 606-611

Xie N., Cui Y., Yin Y.N. et al. (2011). Effects of two Lactobacillus strains on lipid metabolism and intestinal microflora in rats fed a high-cholesterol diet. BMC Complement Altern. Med., 11:53. DOI:10.1186/1472-6882-11-53

Yakubu A., Abimiku H.K., Musa-Azara I.S., Idahor K.O. and Akinsola O.M. (2013). Assessment of flock structure, preference in selection and traits of economic importance for domestic turkey (Meleagris gallopavo) genetic resources in Nassarawa State, Nigeria. Livestock Research for Rural Development, 25 (18). Retrieved August 24, 2013, from http://www.lrrd.org/lrrd25/1/yaku25018.htm 